\title{
Penerapan Desain Pembelajaran Mind Mapping untuk Peningkatan Prestasi Belajar Matematika Materi Lingkaran pada Siswa Kelas VIII SMP Negeri 3 Nganjuk
}

\author{
Aspiatun
}

(C) 2020 JEMS (Jurnal Edukasi Matematika dan Sains)

This is an open access article under the CC-BY-SA license (https://creativecommons.org/licenses/bysa/4.0/) ISSN 2337-9049 (print), ISSN 2502-4671 (online)

\begin{abstract}
Abstrak:
Penelitian ini bertujuan untuk meningkatkan prestasi belajar Matematika siswa SMP yang dilatar belakangi oleh rendahnya kualitas proses dan hasil belajar Matematika siswa SMP, khususnya pada materi lingkaran. Rendahnya prestasi belajar tersebut diakibatkan karena kurangnya kemampuan guru dalam meningkatan prestasi mata pelajaran Matematika siswa Kelas VIII- B di SMPN 3 Nganjuk Kabupaten Nganjuk sebelum mendapat Desain Pembelajaran Mind Mapping dan sesudah Desain Pembelajaran Mind Mapping. Penelitian Tindakan Kelas ini dilaksanakan dalam 2 siklus, Setiap siklus ada 4 tahap penelitian yaitu tahap perencanaan, tahap pelaksanaan, tahap observasi, dan tahap refleksi. Berdasarkan data yang diperoleh selama proses pembelajaran yaitu pada siklus I dan siklus II, peningkatan Prestasi belajar secara sederhana dapat dijabarkan sebagai berikut: Rata-rata nilai test akir siklus I sebesar 72,81 dan siklus II rata-rata nilai test sebesar 82,19, sehingga mengalami peningkatan nilai test sebesar 9,38.
\end{abstract}

Kata Kunci: Model Mind Mapping, Prestasi Belajar, Lingkaran

\begin{abstract}
:
This study aims to improve the mathematics learning achievement of junior high school students which is motivated by the low quality of the mathematics learning process and outcomes of junior high school students, especially in circle material. The low learning achievement is due to the lack of teacher's ability to improve Mathematics grade VIII-B student achievement at SMPN 3 Nganjuk Nganjuk Regency before receiving the Mind Mapping Learning Design and after the Mind Mapping Learning Design. This Classroom Action Research was carried out in 2 cycles, each cycle consisting of 4 stages of research, namely the planning phase, the implementation phase, the observation phase, and the reflection phase. Based on data obtained during the learning process, namely in cycle I and cycle II, an increase in learning achievement can be simply described as follows: The average value of the end of the first cycle of 72, 81 and the second cycle of the average test value of 82.19 , so experienced an increase in test scores of 9.38 .
\end{abstract}

Keywords: Mind Mapping, Learning Achievement, Circle

\section{Pendahuluan}

Pendidikan disekolah yang selama ini dilakukan diharapkan dapat mencerdaskan kehidupan bangsa dan mengembangkan manusia Indonesia seutuhnya, yaitu manusia yang beriman dan bertakwa terhadap Tuhan Yang Maha Esa dan berbudi pekerti luhur, memiliki pengetahuan dan keterampilan, kesehatan jasmani dan rohani, kepribadian yang mantap, mandiri serta rasa tangguang jawab kemasyarakatan dan kebangsaan.

Di sekolah, keberhasilan mengajar guru tidak hanya ditentukan penguasaan pengetahuan guru tentang ilmu yang diajarkan tetapi ditentukan faktor-faktor antara lain: tujuan, metode dan 
cara menerapkan dalam proses belajar mengajar. Karena masing-masing metode mengajar mempunyai kelemahan dan kelebihan, maka untuk mencapai hasil yang memuaskan anatara metode yang satu dengan metode yang lain perlu panduan mengajar yang tepat, sehingga diharapkan kelemahan metode mengajar yang satu akan tertutup oleh metode lain. Pendidikan harus dapat membantu siswa untuk mengembangkan bakat potensi, kreatifitas yang dimiliki siswa secara penuh menuju pembentukan manusia seuthnya.

Untuk mewujudkan tujuan pendidikan perlu adanya upaya-upaya dalam penyelenggaraan pendidikan, seperti peningkatan interaksi timbal balik antaar siswa dan guru, ataupun interaksi antar satu siswa dengan siswa lainnya, siswa juga dapat dirangsang rasa ingin tahunya, sehingga mereka mau mempelajari sesuatu sebelum guru di kelas memberikan materi tersebut. Berdasarkan hal di atas maka penulis tertarik meneliti : " Penerapan Desain Pembelajaran Mind Mapping Untuk Peningkatan Prestasi Belajar Matematika Materi Lingkaran Pada Siswa Kelas VIII-B SMP Negeri 3 Nganjuk".

Adapun ruang lingkup pembahasan memfokuskan pada konteks pendidikan dengan mengkaji penerapan desain pembelajaran Mind Mapping terhadap prestasi belajar matematika siswa SMPN 3 Nganjuk dalam materi Lingkaran dan prestasi belajar siswa Kelas VIII-B yang dijadikan obyek penelitian.

\section{Metode}

Penelitian ini menggunakanrancangan Penelitian Tindakan Kelas (classroom action research) Penelitian terdiri dari 2 siklus, masig- masing siklus memulai 4 tahap, yaitu menyusun rencana tindakan, melaksanakan tindakan, melakukan observasi, melakukan refleksi. Setelah dilakukan refleksi yang mencakup analisis, sintesis, dan penelitian terhadap proses serta hasil tindakan akan timbul perencanaan baru untuk siklus berikutnya.

\section{SIKLUS I}

Siklus I dilaksanakan dalam dua kali tatap muka dengan rincian sebagai berikut.

1. Perencaan tindakan

Membuat perangkat pembelajaran seperti diuraikan berikut ini.

Rencana pelaksanaan pembelajaran (RPP) pada siklus I. Rencana pembelajaran dibuat berdasarkan strategi pembelajaran Desain Pembelajaran Mind Mapping.

Pelaksanaan tindakan Sesuai dengan skenario pada RPP I, siswa mengerjakan LK I Menghitung Keliling Lingkaran. Melakukan diskusi kelompok dilanjutkan diskusi kelas, Guru sebagai fasilitator.

2. Pelaksanaan observasi

Tahap ini dilaksanakan bersamaan dengan pelaksanaan tindakan yang dilakukan oleh peneliti. mengamati aktivitas siswa selama proses pembelajaran baik diskusi dalam kelompok (kerja kelompok) maupun diskusi kelas, mengamati aktivitas siswa dalam menyajikan hasil diskusi, dan merekam situasi belajar selama proses pembelajaran berlangsung.

3. Refleksi

Hasil pengamatan dibahas bersama oleh tim peneliti. Pada siklus I diperoleh gambaran bagaimana dampak penerapan tindakan yang berupa pelajaran terpadu dilakukan. hal - hal yang menjadi permasalahan pada siklus I akan dipakai sebagai pertimbangan untuk membuat perencanaan tindakan pada siklus II. 


\section{SIKLUS II}

Siklus II dilaksanakan dalam dua kali tatap muka, dirinci sebagai berikut:

1. Perencanaan tindakan

Tindakan yang direncanakan untuk mengatasi masalah pada siklus I melalui penyempurnaan peragakat pembelajaran seperti berikut:

Siklus I melalui peyempurnaan perangkat pembelajaran yang meliputi Rencana Pelaksaan Pembelajaran (RPP II) pada siklus II dan Lembar kerja siswa (LKS) untuk tugas kelompok.

Pada tahap ini tidakan yang dilakukan sesuai dengan yang direncanakan pada RPP II yaitu materi Luas Lingkaran dengan Strategi pembelajmaaran Desain Pembelajaran Mind Mapping.

2. Pelaksanaan observasi

Tahap ini dilaksanakan bersamaan dengan pelaksanaan tindakan. Hal yang menjadi fokus pengamatan sama dengan siklus I.

3. Refleksi

Hasil pengamatan dianalisis. Pada siklus II diperoleh gambaran bagaimana dampak penerapan tindakan yang berupa pembelajaran Desain Pembelajaran Mind Mapping dilaksanakan.

Penelitian ini dilakukan di UPTD SMPN 3 Nganjuk, kabupaten Nganjuk kelas yang digunakan untuk penelitian ini adalah kelas VIII-B. Data yang dikumpulkan dalam penelitian ini berupa catatan-catatan dari penelitian, rencana persiapan mengajar, hasil observasi terhadap aktivitas kelas pada waktu mengajar, dan hasil pekerjaan siswa.

Dalam penelitian ini menggunakan analisis data secara deskripsi kualitatif data dan kuantitatif. Analisis data kualitatif diperoleh dari hasil observasi. Analisis data kuantitatif yang berupa angka-angka diperoleh dari hasil observasi angket, dan tes. Hasil observasi yang berupa angka diolah menggunakan rumus atau yang telah ditetapkan untuk memperoleh data kuantitatif. Yang dianalisis secara deskripsif untuk memperoleh data kualitatif.

Peningkatan aktivitas belajar siswa diukur dengan menggunakan rumus $\mathrm{P}=\mathrm{S} / \mathrm{N} \times 100 \%$, dengan $\mathrm{P}=$ Persentase pelaksanaan indicator, $\mathrm{S}=$ Jumlah peroleh skor total individu, dan $\mathrm{N}=$ Jumlah skor maksimal individu. Secara individu, seorang siswa dikatakan berhasil dalam aktivitas belajarnya apabila telah mencapai skor $\geq 75$ dari skor maksimal 100 dengan kriteria aktif. Secara klasikal, suatu kelas dinyatakan berhasil dalam aktivitas belajarnya apabila terdapat $\geq 75$ $\%$ siswa telah mencapai skor dari $\geq 75$ dari skor maksimal 100 dengan kriteria aktif.

\section{Hasil dan Pembahasan}

\section{Hasil}

Hasil test akhir siklus I di peroleh data sebagai berikut: rata-rata nilai test akhir siklus I sebesar 72,81 dan 21 Dari 32 siswa telah memenuhi kriteria ketuntasan klasikal sebesar 65,83\% belum memenuhi kriteria keberhasilan. Tahap Refleksi pada siklus satu menunjukkan bahwa pembelajaran dengan desain mind mapping yang diterapkan berjalan sesuai dengan scenario meskipun belum maksimal. Berdasarkan hasil observasi, prosentase aktivitas belajar siswa yang diperoleh pada pembelajaran siklus I masih perlu ditingkatkan. Sehingga hasil test akhir pada siklus satu belum memenuhi kriteria ketuntasan. Artinya pada siklus satu ada kekurangankekurangan yang nantinya sebagai tolak ukur pada siklus II untuk diperbaiki.

Dari hasil refleksi siklus I masih banyak kekurangan- kekurangan sehingga perlu tindakan untuk menyempurnakan kekurangan-kekurangan tersebut, akirnya peneliti melanjutkan pada siklus II sebagai langkah untuk penyempurnaan siklus I. 
Pada siklus II ini dilakukan Penelitian selama 2 kali pertemuan. Penelitian siklus II dilakukan dengan 4 tahap sebagai berikut:

1. Tahap Perencanaan

Kegiatan yang telah dilakukan dalam tahap perencanaan tindakan ini sama seperti pada siklus 1. Semua instrumen penelitian telah dibuat pada siklus 1 jadi tinggal menggunakan/ menyiapkannya yang berupa:

a. Membuat skenario pembelajaran, dalam Rencana Pelaksanaan Pembelajaran (RPP) yang berhubungan dengan peningkatan kemampuan menemukan rumus dan menghitung Luas Lingkaran dengan desain pembelajaran mind mapping, membuat lembar penilaian.

b. Membuat lembar observasi aktivitas peserta didik.

c. Menyusun lembar Kerja siswa (LKS)

d. Menyusun soal akhir siklus II.

2. Tahap Pelaksanaan

Pada tahap pertama guru mengucap salam mengecek kehadiran siswa guru menyampaikan tujuan pembelajaran, yaitu menemukan rumus luas lingkaran dan menghitung luas lingkaran. Dan guru menyampaikan manfaat mempelajari materi ini untuk kehidupan sehari-hari. Langkah selanjutnya siswa duduk sesuai kelompoknya seperti pada siklus I, Sekaligus guru menyampaikan cara kerja LKS yang sudah dibagi. Anggota kelompok sangat antusias dan aktif mendiskusikan LKS, yaitu menemukan rumus Luas lingkaran sehingga suasana kelas sangat kundusif, guru sambil berkeliling mengamati dan membimbing siswa jika siswa mengalami kesulitan pada saat diskusi . selanjutnya perwakilan kelompok mempresentasikan hasil diskusi LKS, anggota kelompok yang lain menanggapi. Guru memberi pujian dan sekaligus menegaskan bahwa rumus luas lingkaran $(\mathrm{L})=\Pi \mathrm{r}^{2}$, selanjutnya guru bersama siswa membahas contoh soal.

Pada kegiatan penutup, siswa dipandu guru membuat kesimpulan pembelajaran yang di tuangkan dalam mind mapping yang di satukan dengan mind mapping pada siklus I (keliling lingkaran) dan setip siswa mencatat di buku catatan masing- masing. Guru Menginformasikan tugas untuk pertemuan berikutnya pelaksanaan tes akhir siklus II dan di akiri dengan salam. Pada siklus II ini sudah lebih semangat di banding siklus I, rencana pembelajaran dapat terlaksana sesuai dengan scenario pembelajaran.

3. Tahap Observasi .

Dari hasil tes akhir siklus II diperoleh data sebagai berikut: rata- rata nilai test akhir siklus II sebesar $82.19 \%$ dan 28 dari 32 siswa telah memenuhi kriteria ketuntasan sehingga ketuntasan klasikal sebesar 87,50\% sudah memenuhi kriteria keberhasilan. Proses pembelajaran pada siklus II telah berhasil.

4. Refleksi

Refleksi pada siklus II menunjukkan bahwa pembelajaran dengan Desain pembelajaran mind mapping yang diterapkan berjalan lancar dan memenuhi semua indicator keberhasilan sehingga siklus II dihentikan

\section{Pembahasan}

Penelitian ini Merupakan penelitian tindakan kelas yang bertujuan untuk mengetahui peningkatan prestasi belajar dan aktifitas belajar siswa kelas VIII B SMP Negeri 3 Nganjuk melalui penerapan desain pembelajaran mind mapping. Hasil belajar yang diteliti adalah nilai akhir siklus. Melalui Observasi diukur juga aktivitas belajar siswa dengan materi Keliling dan luas lingkaran. 
Peningkatan Aktivitas Belajar selama proses pembelajaran diperoleh data pada siklus I dan siklus II. Peningkatan aktivitas belajar seperti tampak pada table berikut.

Tabel 1. Aktivitas siswa secara klasikal pada siklus I dan siklus II.

\begin{tabular}{llcc}
\hline No & Aktivitas Belajar & Siklus I & Siklus II \\
\hline 1 & Menyenangkan & $73 \%$ & $80 \%$ \\
\hline 2 & Tidak takut & $66 \%$ & $86 \%$ \\
\hline 3 & Senang aktivitas & $70 \%$ & $87 \%$ \\
\hline 4 & Tambah Bersemangat & $78 \%$ & $93 \%$ \\
\hline 5 & MudahMenangkap Pelajaran & $76 \%$ & $95 \%$ \\
\hline & Rata-rata & $73 \%$ & $88 \%$ \\
\hline
\end{tabular}

Dari table 1. di atas tampak ada peningkatan aktivitas siswa dari siklus I dan Siklus II dengan rata-rata siklus I $73 \%$. Rata - rata siklus II sebesar $88 \%$. Sehingga aktivitas siswa dari siklus I ke siklus II mengalami peningkatan. Peningkatan ini menunjukkan bahwa kondisi kelas pada saat diskusi benar-benar aktif, menyenangkan ,tidak takut, bersemangat sehingga mudah menerima pelajaran. Keadaan ini akan berdampak peningkatan prestasi belajar.

Peningkatan prestasi belajar berdasarkan data yang diperoleh selama proses pembelajaran yaitu pada siklus I dan siklus II, peningkatan Prestasi belajar secara sederhana dapat dijabarkan sebagai berikut: rata- rata nilai test akir siklus I sebesar 72,81 dengan ketuntasan klasikal 65,83\%. Keadaan seperti ini belum memenuhi indikator pencapaian. ketuntasan klasikal sebesar 78 sesuai dengan KKM di SMP Negeri 3 Nganjuk untuk mata pelajaran Matematika.

Pada siklus II rata-rata nilai test sebesar 82,19 dengan ketuntasan klasikal 87,50\%, keadaan seperti ini sudah memenuhi indikator pencapaian. Peningkatan rata-rata prestasi belajar dari siklus I ke siklus II sebesar 9,38 dan 21,67\% untuk ketuntasan klasikal, keadaan seperti di karenakan pada siklus II pembelajaran berjalan lancar karena siswa merasa senang dengan penerapan desain pembelajaran maind Mapping.

Dari hasil penelitian pemilihan metode pembelajaran yang tepat juga memegang peranan penting, serta Peran guru untuk memotivasi agar siswa lebih aktif tetap sangat dibutuhkan agar menumbuhkan tingkah laku yang baik, sehingga prestasi belajar meningkat.

\section{Simpulan}

Hasil penelitian terhadap 32 siswa Kelas VIII-B UPTD SMPN 3 Nganjuk Terdapat peningkatan aktivitas belajar siswa, Serta menunjukkan bahwa pemberian desain pembelajaran Mind Mapping dapat meningkatan perstasi belajar siswa pada mata pelajaran matematika pada materi keliling dan Luas Lingkaran. Hal ini ditujukkan dari rata- rata nilai test akir siklus I sebesar 72,81 menjadi 82,19 pada siklus II. Kesimpulan tersebut menunjukkan bahwa prestasi belajar siswa dipengaruhi oleh faktor eksternal, dalam hal ini sikap guru yang menerapkan desain Pembelajaran Mind Mapping kepada siswa.

\section{Daftar Rujukan}

Arifin, Zainal. 1989. Evaluasi Instruksional. Jakart : Gramedia

Arikunto, Suharsini. 1988. Dasar-Dasar evaluasi Pendidikan. Bina Aksara.

Guilford \& Fruchter B. 1987. Fundamental Statistic in Ryschology And Education. McGrow-Hill International Edition. 
Nasution, S. 1987. Berbagai Pendekatan dalam Proses Belajar Mengajar. Bina Aksara.

Slamento. 1988. Belajar dan faktor-faktor yang mempengaruhinya. Bina Aksara.

Tabrani, Dkk. 1994. Pendekatan dalam proses belajar mengajar. Remaja Rokarya.

Winke. 1989. Psikologi Pengajaran. Jakarta: Gramedia 